\title{
Some Phases of Financial Reconstruction ${ }^{1}$
}

\author{
By Paul M. Warburg \\ Former Vice-Governor of the Federal Reserve Board
}

\begin{abstract}
$A \mathrm{~S}$ destruction once begun on the battle field spread its waves A until its effects had reached all parts of the world, so the work of reconstruction will involve the whole globe far beyond the centers originally affected; and as the character and extent of the disturbance differ in each country affected, so the word "reconstruction" will have a very different meaning in the various parts of the world. In some it will indicate the physical restoration of the tangible things actually destroyed, in others financial or commercial rehabilitation; in others it will mean the reëstablishment of normal levels of living and working - a return, more or less, to pre-war conditions. The last named group includes the United States. Considering the question merely from the domestic point of view, "the movement back to normal" would appear as the main aim and characteristic of our own problem of reconstruction.

Several thoughts, however, will at once occur to us at this point and emphasize the complexity of our task.
\end{abstract}

First. That the normal of the past is not likely to be the normal of the future, which raises the further question of what that normal ultimately will be.

Second. That between our present level and that of the future there will of necessity be a period of transition-which raises the question of how long or how short it should be.

Third. That both on account of the moral obligation involved and on account of the effect that reconstruction in other countries must needs exercise upon our own future economic and financial development, we cannot possibly consider the problem as a purely domestic one-which raises the question of purchases on credit by foreign countries and the influence of foreign purchases upon the course of prices.

And finally, that the return to the new normal level must not be construed simply to refer to the level of prices and wages, but that it includes the new norm of government influence in business-which raises the question of the restoration of the freedom of individual action and operation, willingly surrendered in the face of war, but held sacred and inviolable in times of peace.

${ }^{1}$ Address delivered at Atlantic City, N. J., on December 6, 1918, before the War Emergency and Reconstruction Congress of War Service Committees of American Industries, under auspices of the Chamber of Commerce of the United States of America. 
To sketch the problem in its vast outlines is to acknowledge our inability to treat it adequately even within the limitation of some of its phases. For it is evident that the plan to be applied in grappling with the side issues must depend upon the general policy ultimately to be adopted by the government in dealing with the whole problem. That is the reason why in discussing the topic of financial reconstruction only the obvious can be stated with confidence at this time, while wide room is left open for assumptions and speculations whenever we try to go further afield.

My justification for taking up some features of the financial side of the question is that I believe that by carefully analyzing the problem we may assist in clarifying it, and succeed in disposing of some of the fallacies befogging the issue.

In looking into the future we have as yet no definite landmarks upon which we can fix our range-finders in order to ascertain just where the line of demarkation will lie between the transition period and the era following it. We know, however, whence we came, we know our present conditions as our actual starting point, and it must be our first aim to try to gain as clear a conception as possible of our ultimate position, so that in dealing with the interval and the co-related problems, we may map out a course that will lead us towards that final goal. Let us begin then with the obvious things that we may be able to discern distinctly.

As I look through the telescope into the period following that of transition, I see a United States to which the world at large will be heavily indebted, and to which annually hundreds of millions of dollars will be due as interest on loans extended, in addition to the hundreds of millions due in payment of the raw materials we shall be able to spare for other countries. I see an industrially highly developed country which, with the exception of a limited number of articles, will be capable of producing most of the necessaries of life for the consumption of its own people.

I perceive, therefore, a country amply protected by a vast annual international credit balance, a country which by keeping some portion of its foreign security holdings in the form of reasonably short obligations, should be able to protect itself against any serious encroachment upon this creditor position; a country owning a huge gold stock-a country, in short, which need not 
give itself any great concern with regard to the task of maintaining the parity of the dollar exchange all over the world.

I do not wish to pose as what the British wittily have termed a "war prophet-eer," but I much misread the future if it does not have in store for New York the position of a world exchange center, vying with London as a free gold and discount market. As I see it, our future economic position will be of such strength that it will be difficult for many countries to keep their exchanges at par with us. They are not likely to have sufficient quantities of the goods required by us, nor will they have large amounts of gold to spare, and therefore, in payment of the things we sell them and of the interest they will have to pay us, they will have to try to find something else than goods that we may purchase from them; that is, they will offer us the individual or collective obligations of their nationals, or their industrial enterprises, or such securities or assets of other countries as they control. If we want these countries to continue to be able to buy our goods, it is therefore incumbent upon us to prepare ourselves to grant these foreign credits and to buy and assimilate these foreign assets.

\section{Financing of the World's Trade}

In order to carry out this program several things are necessary. First, our banks and bankers must be able and willing freely to extend their acceptances for the financing of the world's trade.

It is inevitable, if our banks and bankers continue to show the same spirit of enterprise and patriotism they have demonstrated during the war, that in the financing of the world's current trade we shall have a very large share. As a matter of fact, we owe it to the world to bear a substantial portion of this burden. To that end the discount rates of the federal reserve banks and the policy of the Federal Reserve Board with respect to acceptance transactions must continue to be liberal. I can well foresee the time when American dollar acceptances will be outstanding to the extent of more than one billion dollars in credits granted all over the globe.

Three years ago, when it was my privilege as a member of the International High Commission to visit South America, I found that the banks in that hemisphere hardly realized that there existed such a thing as dollar exchange or an American bankers' 
acceptance, and our own banks and merchants had to be coaxed into using them. Now these acceptances are well known and eagerly sought all over the world.

And as our banking power and machinery develop, there unfold new opportunities for foreign branches of American banks. There are today about fifty branches of American banks in foreign countries, besides a considerable number of affiliated banks and sub-agencies largely in Latin-American countries, and more are being opened every month of the year. The Federal Reserve Bulletin in its recent numbers has given the fullest data concerning the operations of the banking institutions engaging in these foreign enterprises. They are covering at present almost every country in South and Central America, they have penetrated the Philippines, Japan, China and India, and we find them established in England, France, Italy, Spain, Belgium and Russia.

But while much has been accomplished as a beginning, while the marvelous strides that our banking system has made during the war are as unparalleled as the rapid creation, equipment, training and transportation of our armies, more remains to be done. While it is most satisfactory to note that several discount companies and acceptance corporations have been organized, it is my belief that the future will show a very distinct need for a larger number of acceptance corporations.

As the liberty loan bonds are absorbed by the public and as the paper secured by these bonds and rediscounted with the federal reserve banks is liquidated, the enormous resources of the Federal Reserve System will become available for regular investment in bankers' acceptances to a larger extent even than in the past, and will prove a tower of strength, protecting our discount market at rates which will compare favorably with those of the strongest amongst the old established countries.

These conditions are likely to bring about a constantly growing demand for American acceptances, and I hope that not only banks and acceptance corporations but also private banking firms will energetically cultivate this new field of enterprise. As is well known, private bankers were pioneers in England in developing the foreign acceptance in business.

The war being over, it is now the privilege of our bankers and 
financiers to make themselves generals in the arts of peace, and to call out as volunteers the best talent, now happily again available, for the constructive pursuits of commerce and trade in all parts of the world.

There is in this call no challenge to England; she will, I am certain, retain her logical and traditional position of a world center of commerce and finance. Moreover, once we return to the time when trade between nations is no longer financed by the issue of government bonds, the old machinery of bankers' acceptances and investment banking will be so heavily taxed in both countries that England and the United States, soon to be joined, we all hope, by France, will be only too glad to find partners with whom to divide the burden and, rather than envious competition in securing the load, there will be a tendency of wishing to place a fair share of it on "the other fellow." No doubt some of the neutral countries, whose financial strength and independence have greatly increased during the war, will play an important rôle; while Germany's place as an international banker will have to be considered as vacated for some time to come.

Bankers' acceptances, however, while important factors as temporary equalizers of international balances, and invaluable, furthermore, in their incidental effect in creating centers into which other commercial and financial transactions will naturally flow, cannot be expected to offer the proper medium for settling the vast permanent indebtedness to us which we expect to see accumulating from year to year. These large balances must be offset not by temporary credits but by an outright transfer to us of foreign assets. This may be brought about essentially in four ways:

1. The debtor country may sell to our government its own government obligations (our government in turn financing itself by the sale of United States Government bonds substantially in the same manner as adopted in financing our Allies during the war). Or

2. The debtor country may sell to our investors (instead of to our government) :

(a) Its own government obligations, or

(b) Industrial stocks or bonds originating within its own boundaries, or

(c) Stocks or bonds owned by it but issued in other foreign countries.

The first method is not likely to be employed extensively beyond the beginning of the transition period. The other three 
methods are the ones that in the long run we may expect to see develop as the most practicable forms for which we must prepare ourselves.

In order to bring about in the United States the successful absorption on a large scale of foreign securities, it is necessary that our investing public be educated properly to appreciate these foreign investments. That will only be possible as our banks and our business men going into foreign countries bring back to the "folks at home" frank and reliable information concerning the risks and chances of the proposed investment, concerning the resources of such countries, the character of their people and their political and economic conditions.

Intimate commercial relations with foreign countries create the atmosphere of understanding, interest and sympathy which alone renders possible comprehensive international financing; and inversely it is such financing that encourages the growth of trade relations. There is a relationship of close mutuality between business man and banker in this respect. For the fullest success one is dependent upon the other, and the country at this juncture depends upon both. To go out into the world, to study foreign conditions, to open new avenues of commerce and finance and to develop in this country a group of men whose word and judgment with regard to foreign enterprises we shall willingly trust, is a national enterprise that should appeal to the ambition and public spirit of the ablest of our coming bankers and business men.

In times of temporary adverse trade conditions or unexpected emergencies, the ownership of foreign securities is moreover of the greatest value to the country. We need only to think of the invaluable source of strength they proved to England during her hours of trial. I believe we may safely say that it was the use of these foreign holdings (North American and others) that enabled England to finance her own foreign purchases and those of some of her allies without breaking the rate of exchange of the pound sterling during the first period of the war. But from this episode we should draw the lesson that the advantage of holding foreign securities consists in no small degree in the ability of selling them in several markets, and in creating a market here for foreign securities we ought to remain mindful of that fact. 
Before 1914, the large holdings of American securities in Europe and their wide market on both sides of the ocean furnished an important instrument for equalizing temporary debit balances by the so-called "arbitrage" of securities. The back flow of our own securities must have destroyed very largely these economically important pre-war conditions. We can well imagine that government bonds with international markets will play an important rôle in restoring the basis for an easy exchange of securities, that is, a healthy trans-Atlantic bond arbitrage. In going into these new fields of foreign investment and trade, let us start out with a generous, sympathetic and receptive mind; with open purses-but also with open eyes and conscious of our serious responsibilities in the matter.

It is unfortunately true that wherever the faithful pioneer goes, there also migrates the crook. In opening the markets to foreign financing, almost every country fell victim to the occasional robberies perpetrated by reckless promoters. The local knowledge of American business men and bankers living in these foreign countries may prove an invaluable protection in scrutinizing these propositions. But, if I may be permitted to express my thoughts in the premises, I believe that for the better protection of both the public and the careful and self-respecting banker, it would be advisable to establish some generally accepted rules governing the information to be contained in a prospectus offering for sale foreign securities. Every great international market enjoys such rules, established either voluntarily by the stock exchanges or by the government.

If we are to be a world center of finance, as I am profoundly convinced we shall be, I believe we ought to take steps that will give to the American prospectus the same standing and prestige as is enjoyed by those of the leading European markets. I can well imagine that by common and voluntary agreement some sort of a future capital issues committee might be organized in each federal reserve district to give its stamp of approval to every such prospectus before the quotation on the stock exchange be granted or the offer be made.

Such approval would not signifiy the passing upon the intrinsic merit of the security involved, but it would give assurance that all essential facts, and nothing but authentic information, be 
contained in the prospectus and that they be stated over the signature of the borrowing government or corporation and the issuing house. This is, as a matter of fact, no more than a responsible issuing house would observe. It would be a burden, therefore, only upon less conservative firms, upon which a check ought to be exercised. While, no doubt, some red tape and delay would be involved in such a proceeding, it would in the long run prove well worth while to submit to it. The chairman and governor of the federal reserve bank of the district might be invited to head the committee, as at present. They and others would, no doubt, be found willing in the general interest to shoulder the burden.

When the present Capital Issues Committee in due course, by the expiration of the act, discontinues its operations, it is possible that such new local capital issues committees might exercise a very important function in protecting the country in this further respect: Issuing houses in Europe do not generally enter into contracts for the purchase of foreign securities without first inquiring at their headquarters whether or not such issue is in the public interest. It must be borne in mind that when concluding these loans not only the relationship with the borrowing country must be considered, but also the condition of the purchasing country as a whole. Excessive foreign loans may at times adversely affect the entire network of trade balances, exchanges and interest rates, even though the transaction may be of great advantage to particular industries, and even though the contracting country itself may be heavily in our debt. The situation as a whole, therefore, should be carefully weighed in such cases by the Federal Reserve Board which, when approached through the local capital issues committee, would give its advice.

It may be timely to point out in this connection that foreign bonds payable in several currencies would prove of great value in times when gold exportations might become imminent in consequence of unexpected temporary financial dislocations. In such circumstances interchangeable international bonds could well be sold abroad in order to replenish our foreign balances, warding off to that extent exportations of gold.

In sketching this program for the future we cannot be unmindful that in certain important respects it will not meet our imme- 
diate needs, because it will take time to develop in the United States as wide a market for foreign securities as is here contemplated, while most urgent demands by foreign nations are near at hand. We know that almost all European countries for a prolonged period will require food, or steel, or copper, or cotton, or machinery with which to rebuild their life and industries. Many of them at present have neither gold nor goods with which to pay us. Individual and banking credit in some cases has been seriously affected, and in others has not yet had sufficient time to establish or reëstablish itself. Without doubt we shall consider it our proud privilege to give whatever we can spare to those that deserve our aid, particularly to those who, like France and Belgium, have an undoubtedly valid moral claim on us, and to that end we shall have to continue to reduce our own consumption to the necessary degree.

It is at this point of our consideration, however, that our ship strikes a fog bank and that we shall have to feel our way in the mist as best we can. There are quite a number of factors about which, for the time being at least, we are uninformed. We do not know whether during the transition period Congress is going to authorize advances by the United States to foreign countries in order to provide the means with which to pay us for their purchases of foodstuffs or other necessities. At present the symptoms point the other way.

If, however, the government itself is not going to finance the sale of these goods, the volume of such foreign purchases is likely to be reduced or at least delayed so as to synchronize with the amounts of dollars that can be raised here by the opening of temporary banking credits, or by the free sale in our market of foreign government bonds or foreign assets. In that case our exports are likely to move at a slower pace and there is less likelihood of a congested demand for goods for export, and therefore, prices are likely more promptly to find their own natural level.

Conversely, should the United States Government decide to advance the amounts involved to the purchasing nations, greater immediate stimulation of certain export industries would follow, coupled with the resulting possibility of continuing for some time at least the exercise of a certain control of prices and distribution, thereby causing a more gradual decline. Of the two courses our 
first impulses, I believe, would make us choose the latter. Closer study is likely, however, to gain our support for the first of the two methods.

There is much to be said in favor of a quick return to the natural basis. While it must be conceded that unhampered development may temporarily produce a greater shock, we must bear in mind that on the other hand trade and industry are unlikely to proceed at full speed until there prevails a general and confident feeling that a natural solid basis has been reached. What would be gained by governmental assistance to our foreign purchases would be lost, therefore, by the creation of a sentiment of reserve and hesitation caused by the hot-house atmosphere.

Moreover, now that the war is won, we cannot blink the fact that impatience is general to shake off restrictions and bothersome regulations, and there is grave doubt as to whether an effective control of output, distribution and prices could be continued any longer. While the cushioning of the shock might appear very desirable on account of its bearing upon unemployment and wages, the fact must not be overlooked that by the systematic and wise curtailment during the war of expenditures for maintenance and new constructions, for necessaries and luxuries, we have now happily stored up a reserve purchasing power which, together with the natural foreign demand, should prove a very efficient shock absorber.

These conditions would not appear to warrant the fear of the imminence of very drastic convulsions in the labor market. But even a temporary jolt should not frighten labor, provided that there results a prompt establishment of a solid basis on which business can develop healthily and freely. Weighing all pros and cons as far as we are able to see them and realizing that requirements may differ in the several branches of industry and trade, it would seem that on the whole the evidence favors an early withdrawal of the hand of government in regulating production and prices. ${ }^{2}$

The policy indicated by the Treasury of prompt liquidation of government contracts, even though compensation for cancellation

2 I am not including the activities of the War Trade Board, whose control, in certain respects, may have to be continued until the free use of shipping facilities will be restored to our trade. 
might involve large sums, appears most advisable in the circumstances. Prompt payment by the Treasury of all such obligations would ease very materially the general situation and it would enable industry to clean the slate rapidly and thoroughly and get ready for the new business that knocks at our doors. The above is stated with the greatest possible hesitation by a skipper who knows full well that he is in a fog, but who, having recklessly agreed to discuss this topic, has no choice but to go ahead on the best observations and soundings that he is able to make.

But whether or not our assumptions be correct, in trying to survey the field of our future financing, we may take it for granted that, should our government cease to make advances to our Allies, some of them are most likely to offer for sale in our market their own government bonds or notes, or their industrial properties. I feel certain that vast amounts of the obligations of our strong friends will find a cordial reception here and will be readily absorbed; but taking it all in all it appears extremely doubtful whether our investment houses will find it possible to place foreign securities on a broad enough scale to meet the large foreign requirements for our goods. The task will be made all the more difficult, because, as some of these countries have just passed through a period of unrest and great financial strain, we may expect the investor to insist on some evidence that new political conditions have come to stay and that he may rely on an undisturbed economic development before he risks his money.

On the other hand this period may offer great opportunities for the acquisition of most valuable foreign properties. Some nations, particularly those with strong credit, might possibly prefer sooner or later to dispose of some of their national securities or assets rather than to increase their indebtedness to us by the acceptance of further loans; other countries may have to sell in order to pay their debts because their national credit has been destroyed. From the business point of view it would obviously be to our advantage to buy assets of this sort (or, as the case may be, to make advances secured by such assets with an option to buy them) instead of taking an unsecured long-term foreign government obligation.

It is evident why, in the long run, it is more desirable for the United States to acquire the electric light and power plants, 
telegraph and telephone lines, railroads, mines, or other industrial plants, than to advance to others the money with which to carry these properties; for whoever owns and controls these foreign plants is most likely to secure for his nationals the orders for raw material and manufactured article that go with their upkeep and development. Regular orders of this nature have shown themselves to be a most valuable nucleus around which further business crystallizes.

It is estimated that England, France and Germany before the beginning of the war invested annually an aggregate of over a billion dollars in foreign countries. For more than four years countries like the South and Central American republics and China have not been able to secure foreign funds in substantial amounts, and while the war has taught them the necessity for a greater degree of thrift and more extensive reliance upon their own resources, their accumulated appetite for foreign capital must now be large.

Add to that the demands of European nations, new and old, and it will be clear that by sheer force of circumstances, even though England, France, Holland, Japan, the Scandinavian countries and others will take their full share of the burden, we shall soon be driven into a position of great importance in international finance, and that this responsibility will be facing us long before we may expect to see our market for foreign securities develop far enough adequately to meet the situation.

I believe that so-called "investment trusts" will ultimately play an important rôle in solving this problem. Companies of that character are well-known in England, particularly in Scotland. As their name indicates, they invest their funds in foreign securities and against their assets they issue their stocks and bonds for sale in the home market. One important corporation of this description has been launched in the United States, the American International Corporation. More such companies, I think, are bound to be created, but it will take years to establish their prestige and standing all over the country and to prepare for their securities an investment field wide enough to fill our needs. 


\section{Plans for a Peace Finance Corporation}

In these circumstances, it occurred to me some time ago that by converting the War Finance Corporation into a peace finance corporation and authorizing it to acquire directly, or make advances on foreign securities, we might create an instrument that would promote our foreign trade and at the same time greatly assist foreign nations in need of our support during a period of political and economic transition. Such a peace finance corporation, enjoying the prestige and strength flowing from the $\$ 500,000,000$ capital subscribed by the United States, could exercise effectively its power, within certain limits and for a limited number of years, to issue its own obligations against the foreign securities acquired. ${ }^{3}$ In doing so it might render services of the very greatest value in bridging a critical interval. At the same time, it would keep the government out of direct touch with business transactions, with which, for a thousand obvious reasons, it had better remain unconnected.

For the sake of both our domestic and our foreign problems, I believe a plan of this kind is deserving of our most careful consideration, even though $\mathrm{I}$ am reluctant to suggest it because of my strong belief that at this time we should remove rather than construct war emergency machinery that draws government into business and on account of other serious and valid objections which at once occur to us.

The greatest difficulty, and one that cannot be weighed too conscientiously, is that of devising a plan which will provide a sufficient assurance that we may rely on securing men able, expert and independent enough to be entrusted with the administration of funds amounting to possibly billions of dollars, men who would have to be vested with wide powers in dealing with what, in effect, would amount to the people's money. In order to win the war, and while it lasted, we were willing to concentrate such powers in the hands of a few. Would Congress be prepared to go that far for purposes of reconstruction? That is doubtful, and personally I believe that, in spite of its obvious necessities and advantages, the step, involving as it does transactions with

- These obligations should not be eligible as collateral for notes rediscountable with federal reserve banks. They should be placed only as fast as they can be absorbed by the investors. 
foreign countries, could safely be undertaken only if we could remove every reasonable doubt with respect to our ability of securing the proper men and of keeping the corporation's management so separate and distinct from the direct responsibility of the government as to protect both the government and the corporation from any embarrassment likely to result in dealing with foreign nations.

A solution might be found by providing that the peace finance corporation should be administered by a board of directors, of whom one each, with the approval of the President, would be designated by the Secretary of State, the Secretary of the Treasury the Secretary of Commerce, the Federal Reserve Board, the War Industries Board, the War Trade Board, the Shipping Board and the Food Administration (each selecting at the same time a substitute director for their appointee). These directors then would elect the general manager and other officers.

A method of this kind would be likely to secure a non-partisan expert administration: a majority would be appointed by nonpartisan expert men of national reputation and of widely divergent interests. I think a board of that kind might safely be entrusted with the necessary wide powers; it would embody all the elements that are at present charged with the duty of regulating commerce and finance, particularly in their relation to foreign countries. In case of vacancies occurring after one or more of the appointing boards had ceased to exist, other boards such as the Federal Trade Commission and the Tariff Board might take their place, or the Board of the Peace Finance Corporation itself might be empowered to submit to the president names of candidates. There may be many better ways of appointing the board; the above method is suggested simply for the purpose of submitting an illustration.

In many foreign countries there are men now on the ground, serving as emissaries of the Department of Commerce, or as representatives of the Treasury, or acting in connection with the business operations of the army and navy or the American relief organizations. Would it not be possible to constitute from men thus available abroad and the best men qualified in the United States, advisory commissions to cover each country, not only in Europe but also in South America and Asia? These men might render invaluable services to a peace finance corporation, and 
ultimately they would become important factors in creating in the United States the atmosphere of knowledge and understanding of foreign conditions so important for the development of our future trade and finances. At the same time it will be very desirable to have available in some of these countries groups of men who will keep an eye on the proper distribution of goods furnished by us.

Whatever form of financing, however, the reconstruction period may bring, whether securities issued by our own government, or by a peace finance corporation, or by foreign governments or foreign corporations, it is certain that their successful absorption will depend upon the saving capacity of our people. I believe we cannot emphasize too strongly that the time has not yet come when our people may relax their efforts to curtail unnecessary consumption, both for the sake of releasing for export the greatest possible quantities of goods, thereby stimulating our export industries, and for the purpose of accumulating funds available for investment. The slogan "don't stop saving food" would gain in scope and strength by abbreviating it into "don't stop saving!" Our more than twenty-one million liberty bond holders must be trained to become permanent investors; thrift must become a national virtue, a priceless inheritance left to us by the war. The splendid saving mechanisms now in use should be continued and expanded; they should not be permitted to die out when government borrowing ceases.

It is most important that our coming victory loan be absorbed so far as possible not by bank borrowings, but by genuine savings. Thanks to the strength provided by the Federal Reserve System, our banks have been able to meet the strain of the war in a most admirable way, and, as in every previous loan, they will be found prepared for whatever burden the next loan may bring.

But do not let us be unmindful of the fact that since our entry into the war the reserves of the federal reserve banks have fallen from 85 to about 50 per cent; that the aggregate investments of federal reserve banks have increased in that period from $\$ 225,000$,000 to over $\$ 2,300,000,000$; and that the proportion of national banks' investments to deposits at present amounts to 130 per cent against 110 per cent at the beginning of the war in 1914 . 


\section{Government Bonds and World-Wide Inflation}

We are near the crest of the wave of world-wide inflation. As it was generated and fostered by a chain of interlocking effects and reactions of extraordinary demands for certain goods, reduced power of production of others, rising prices, rising wages, vast issues of government bonds and circulating notes, so with the approaching end of the issues of government loans we may expect to see the beginning of a gradual contraction of note-issues and deflation of prices and wages ${ }^{4}$ and a return to more normal conditions of production and consumption.

So far as the banking situation is concerned, deflation will have to be brought about primarily by the people's efforts to save and by a contraction of loans following the shrinkage of prices of goods and reduction of the volume of inventories. On November 8 , the 751 member banks in leading cities submitting weekly reports to the Federal Reserve Board held $\$ 1,200,000,000$ of loans secured by government war obligations in addition to $\$ 1,806,000,000$ of government securities (exclusive of $\$ 268,000,000$ deposited for the issue of national bank currency), making the total holdings by these reporting member banks of government war obligations and paper secured by such obligations in excess of three billion dollars, of which a substantial proportion was pledged as security for loans obtained from federal reserve banks. On the same date the amount of this class of paper which the federal reserve banks had discounted for their members aggregated $\$ 1,317,000,000$.

The government bonds held by the banks ought to be absorbed by the public as fast as possible and the expanded position of both member banks and the federal reserve banks correspondingly lightened. Depositors by turning into investors would reduce our deposit structure, which from the beginning of the war in 1914 has risen from $\$ 21,330,000,000$ to about $\$ 32,000,000,000$, and thereby decrease the banks' reserve requirements. This in turn would have the effect of reducing the re-discounts made by member banks in order to provide the necessary reserve balances with federal reserve banks.

- Wages control prices and prices control wages; they have to move together. I cannot but believe that Mr. Gompers had in mind in his recent speech the preservation of the relative position of wages; that is, their purchasing power (based upon index numbers or what is spoken of as real wages, as distinct from nominal wages). Any other thought is an impossibility. 
While it is possible that the aggregate of investments of the federal reserve banks will still rise in consequence of the payment of the installments due on the fourth liberty loan and the victory loan to be expected in the spring, we must hope that the peak may be reached in the near future and that from then on we may witness a continuous and substantial decline in bank investments and a corresponding rise in the percentage of reserves.

Nothing could be more beneficial to the prestige of the United States as a world power in finance than the early and courageous lifting of the gold embargo. It is true that before contemplating this step, it will probably be necessary to have an ample tonnage at our free disposal for the unhampered transportation of our goods (and other conditions will have to be considered which it would lead too far here to discuss), but it is also true that the stronger our gold reserve at that time, the more readily will we be able to envisage with complacency the probability of the consequent exportation of sums of gold which, conceivably, may amount to hundreds of millions of dollars.

It is for this very important reason that it is sincerely to be hoped that the people by saving and curtailment of unnecessary consumption and expenditures, and that the business community by a program of wise moderation, particularly dealing with nonessentials,--and as long as this can be done without creating unemployment,--will do their share in consolidating both our gold and investment strength, on which two factors, our ability to secure our proper position in foreign lands and our power to act boldly and generously in dealing with other nations, are largely predicated.

Over-expansion of deposits and note-issues must not be permitted to tie up our reserves to such a degree as to interfere with our power to let gold go out freely. While we are still in a position of great strength, we must remain conscious of the necessity of not forgetting our limitations.

If by the exportation of large amounts of gold or a continual increase of investments our Federal Reserve System's cash reserves would fall from 50 to about 40 per cent, that by comparison with other countries would still look like a very high reserve. Do not let us forget, however, that in Europe reserves before the war were considered to be near a normal level at approximately 60 
per cent, and that that was at a time when central bank countries were saturated with gold, owing to the hundreds of millions in actual gold carried in the pockets of the people, while now this important secondary reserve has been wiped out in almost all leading countries. They have wisely concentrated that gold in the central banks in order to have it serve as a basis for their vastly increased note and deposit obligations. Iogically, future central banks' reserve standards ought, therefore, to be higher than those of the past. While we must resign ourselves to the conclusion that it will be a "long, long way" to the realization of any such hope, it is all the more evident how important it is for all countries firmly to envisage this goal of strengthening their present financial position by a gradual deflation, and continued efforts to concentrate all scattered gold.

The world balance sheet has been "watered" by issuing war loans and currency, against things already consumed or of no permanent value, to an aggregate appraised to exceed the estimated pre-war wealth of England and Germany combined. The squeezing out of this water by gradual amortization of war loans and contraction of note issues will prove an important factor in reëstablishing pre-war levels of prices.

Some writers hold to the view that increased production of goods rather than banking deflation may bring us back to a normal relation between money and goods. My own belief is that the solution must be sought in efforts from both ends. The resultant line indicating the trend of prices and deflation would then lie somewhere around midway between the highest and lowest points.

Perhaps I should say a word at this juncture concerning the much mooted question of the demonetization of gold as a world medium of exchange. In considering the suggestions made in this connection I have to think of the deaf old lady who, when asked by her table neighbor whether she liked red bananas, answered: "No, my dear, I prefer the old-fashioned night shirt." I confess, when dealing with this problem, that I, too, am old-fashioned. I believe that gold as a medium of actual circulation within the border lines of countries will more and more be relegated to the past; but that as a basis for an elastic circulation and as the ultimate means of settlement of international balances, it will continue to dominate the world. It will not be dethroned for 
the reason, if for no other, that such a step could only be taken by mutual agreement between gold debtor and gold creditor. The position of economic superiority held by a creditor country owning a large stock of gold is, however, of so immense an advantage that it will not be voluntarily relinquished by the large number of nations that are the beati possidentes.

Nor do I believe that the world has turned far enough into a family of communists seriously to consider the pooling by all countries of their holdings of gold. As long as nations have separate national budgets and obligations, they are likely to wish to retain a distinct ownership of their assets. The problems of reconstruction are immense and immediate; the new structure must be erected on the most solid foundation and built with material that is thoroughly tested and promptly and actually available.

Nor can we deal effectively with the foreign exchange question without first freeing our minds from doubtful theories. We must cling to the old dogma, that foreign exchange will continue to be the result of the foreign trade and credit of each individual nation, the balance, so far as not squared by the flow of goods and loans and securities (including bills of exchange) or bank balances, remaining to be settled in gold. The war, drastically obstructing all these natural currents, brought violent and most regrettable disturbances to the foreign exchange markets. But we have seen that the very approach of the armistice, promising the return of normal trade conditions, turned back our exchange rates towards their fairly normal level.

I do not believe, therefore, that there is any necessity for the establishment by the government of a foreign exchange bank, which has been urged as a reconstruction measure, for the purpose of keeping dollar exchange at par, or our discount rate for bankers' acceptances at $3 \frac{1}{2}$ per cent, or for providing the country with adequate foreign exchange and credit facilities at fair and equitable rates. If it should be shown that American banks and bankers are so lacking in spirit of enterprise that our business men, at fair rates of compensation, cannot secure adequate facilities for the carrying on of their foreign transactions, then such banks should be organized.

In that case, however, it should not be a note-issuing bank, 
but a plain and unhampered business organization under government control. So far nothing has changed my knowledge and conviction that the foreign exchange business in times of peace is being transacted on the most modest margin of profits, that our American banks, since the shackles were taken off them four years ago, ${ }^{5}$ have moved rapidly into foreign fields and that they may be relied upon to do their share in the future.

Attention has been drawn to the preliminary steps taken by many European nations for the organization of banks designed to protect the foreign exchanges of their respective countries. But the conditions of these nations are not ours. Countries that are dependent upon the importation of goods and at the same time have to find means of annually remitting abroad large sums in payment of interest and amortization have a very real and serious problem on their hands, one from which, happily, we have reasons to hope to be immune, at least for some years to come.

With the vast credit balance annually accumulating in our favor, adverse exchange conditions, barring unforeseen emergencies, can normally be brought about only by excessive foreign investments and these can be adjusted by a modification of our financial policy at home, but not by the operation of a foreign exchange bank. Nor would it have been within the power of such a foreign exchange bank to stabilize our dollar exchange during the war.

It is now well understood that apart from the interruption of our trade with neutrals, the prevailing and regrettable disturbance in our neutral exchanges was largely a question of the use of the proceeds of our loans granted to our Allies, and of other "force majeur" influences which it would lead too far to enter into, but which would have been beyond the power of such a bank to regulate. As stated before, when the seas are open to our unhampered trade and when our foreign loans are under proper control, with our huge gold stock and an effective discount market, our foreign exchange situation can be protected without the creation of a new government bank.

Nor is such a bank necessary in order to put our discount rates

- It was only two years ago that the power was granted to national banks to combine in holding stock in banks organized to do foreign business. The national charter for such foreign banks has not yet been granted, in spite of the urgent and persistent representations of the Federal Reserve Board. 
on an equal level with those of London. It cannot be denied that it is an anomaly, which rankles in the minds of some of our critics, that our acceptance discount rate should at present be at $4 \frac{1}{4}$ per cent, while the British rate is at $3 \frac{1}{2}$ per cent at a time when England is borrowing from us at a rate well in excess of $4 \frac{1}{4}$ per cent.

So long, however, as the United States Treasury has to raise about one and a half billions per month by the sale of Treasury certificates at $4 \frac{1}{2}$ per cent, it is evident that a reduction by the federal reserve banks of their discount rate to $3 \frac{1}{2}$ per cent would only have the effect of inducing the banks and trust companies to sell all their acceptances to the federal reserve banks at that rate, in order to buy Treasury certificates at $4 \frac{1}{2}$ per cent, or commercial paper at 6 per cent.

In other words, it would tend to encourage expansion and at the same time destroy the broad market for acceptances which, as a result of the labor of several years, has been developed, with a constantly growing number of banks purchasing these acceptances. The low rate, if adopted, would be likely to make the federal reserve banks the only market. If, on the other hand, the Treasury reduced its rate on certificates to $3 \frac{1}{2}$ per cent it would court certain failure in its attempt to raise the vast amounts required each month.

As against these conditions, it may be taken as a fact that the low acceptance rate established in England proved of a very real value to our Ally on account of its bearing upon the British Government's gigantic and highly successful loan operations in the home market. Must we not ask ourselves whether that was not a sufficient compensation for the temporary disadvantage at which we were placed? Was not the common object to be gained more important than the question of the relative position of vantage between allies?

As stated before, we may expect that anomalies of this kind will cease as soon as Treasuries discontinue to issue government loans and when the natural flow of money again dictates the rate policy of the countries under the leadership of their central banks. It cannot take long for a natural adjustment to take place on these lines and we can well afford to be patient in the interval, whether it extends over half a year or even a little longer, during this transition period of reconstruction. 
Was it not the redeeming feature of the horrors through which we were passing that for a common aim men were willing to share with one another suffering, deprivation and death? And is it not one of the most inspiring features of reconstruction that a spirit of competition in giving and sharing with one another has come to us to take the place of the one-time spirit of keen competition for possession and position?

Is the United States to be the Leading Financial Country?

In thinking of financial reconstruction and of the financial world of the future, do not too many amongst us have this one thought uppermost in our minds: is the United States hereafter going to be the leading financial country? In other words, are we going to take England's place as the foremost financial power? Do not these men forget that if England were to surrender her entire trade and banking to us we should collapse, and that if we were to unload all our business on her, she would break down under the burden?

The whole truth of the matter is that we have both grown to be pillars supporting the same structure and that neither can fall or become weakened without bringing danger or disaster on the other. England, herself the owner of billions of foreign obligations, will remain the banking center of Europe, a world clearing house for goods and credits. I believe that her banks and ours will be found in close coöperation, sharing the burdens in bond issues and credits, and relieving each other as the tide may swing from time to time.

Personally, I think it is finer and healthier for us not to think so much of the rank as of the responsibility of our position. Amongst nations, as amongst men, it is not prudent to place one's self on a pedestal overtowering the rest. Whoever rises too far above his neighbors ultimately makes himself their target.

Moreover, conditions of too glaring advantage do not remain long without the disproportion being adjusted in one way or another. An over-abundance of capital and material on our part will soon draw towards our shores as an equalizing force a stream of men anxious to divide with us our position of advantage, and surplus capital flowing into poorer countries will help them to develop their own resources. The ultimate course of the process 
of adjustment will largely be influenced by the attitude and power of labor, and our future tariff policy.

If I read aright the signs of the times, England and the United States, soon to be joined by France, allies of the past, will be partners rather than competitors in the future-partners not of a close corporation to the exclusion of others: it will be a partnership wide open for any respectable new associate wishing to enter. Or perhaps we might more properly term them joint trustees, with others, administering a great public trust. If there is to be immediate and intense competition between their peoples, it ought to be on this one and only ground: "Who will be able to save most in order to be able to help most."

The ownership of no less than $\$ 8,000,000,000$ of foreign government obligations (probably billions more before we are quite through) conveys to the government of the United States the possession of a master key controlling the foreign exchange market for some years to come.

Nobody is wise enough to say today what the ultimate disposition of these foreign bond holdings will be. Some bonds may be actually paid off when due; others may have to be renewed by our government; in other cases foreign governments, when their bonds mature, as a renewal operation may offer their own bonds for sale to the American investor (instead of to our government).

We may assume, however, with entire confidence, that the United States is not going to be a hard and exacting creditor. While our government may find that, as a matter of protection against unexpected economic or political developments, it may be advisable to keep a certain portion of our foreign loans in bonds of a reasonably short maturity, renewable from time to time, there cannot be any doubt that the decisions of any future administration concerning the ultimate liquidation or continuation of these debts will not be reached from mercenary or selfish motives, but that they will spring from considerations of the larger duties towards the world as a whole, and from minds fresh with the memories of the sacred purposes for which these obligations were incurred.

It would unduly tax your patience to give a complete list of the things in which I do not believe, but it may not be inopportune for me to digress here for a moment in order to express the hope 
that Congress may see its way clear to exempt from taxation the interest received by foreigners on bank deposits in the United States, or on their investments in loans, discounts or American bills of exchange. Other countries, e.g., England, have imposed taxes on income received by foreigners on permanent investments; but England has never undertaken to tax foreigners on revenues from sources of income which do not constitute permanent investment. England, not only commercially but also financially, is a free trading country, and it is largely to her iiberal attitude in this respect that she owes her position as the world's banker.

Petty and vexatious taxation of revenues from bank balances and bills of exchange will result in placing a severe handicap upon American banks in their efforts to give to American paper and American balances the same standing as that enjoyed by their British brethren. Such taxation not only impedes the free flow of money but in the final analysis hurts the American borrower, who will be the one to "pay the piper" by being compelled to stand the higher interest charges which would result. I should earnestly urge, therefore, that Congress examine this question very seriously when framing the revenue bill now under consideration.

Just as I was finishing the writing of this article, there came to my knowledge an abstract of the report of the British Committee appointed to investigate the question of currency and foreign exchange after the war, of which Lord Cunliffe, the esteemed ex-Governor of the Bank of England, is the chairman. It was extremely gratifying to find that the conclusions reached by this committee bear out entirely the thoughts that I have ventured to express in this paper with regard to Treasury borrowings, discount rates and deflation.

The report urges as prerequisites for the restoration of an effective gold standard, "which should be restored without delay":

The cessation of government borrowing as soon as possible after the war, and the provision at the earliest possible moment of an adequate sinking fund for the purpose of bringing about a regular annual reduction of capital liabilities;

A cautious reduction of the outstanding uncovered note issue and a greater concentration and strengthening of the gold reserve;

And, furthermore, the bringing into effect of the "machinery, which long experience has shown to be the only effective remedy for an adverse balance of trade 
and an undue growth of credit." This machinery is defined as "the raising and making effective of the Bank of England's discount rate, which before the war operated to check a foreign drain of gold and the speculative expansion of credit." "This necessity," the report says, "cannot, and should not, be evaded by any attempt to continue differential rates for home and foreign money after the war."

Lord Cunliffe's sound advice to let business return as soon as possible into its old and tried channels will no doubt be heartily acclaimed by our business men and bankers.

Under the able leadership of the Secretary of the Treasury-in whose retirement we regretfully lose a courageous and efficient general, deserving of the country's deep gratitude,-our task of war financing has been most brilliantly performed. The Federal Reserve System, now unfolded to a position of power and influence far beyond the early expectations of its very proponents, and the banks of the country, placed through it upon a new basis of safety and of wider scope of operation, will show themselves physically and intellectually equipped for their larger tasks whenever the moment comes for the Treasury safely and properly to return to a peace footing in the exercise of its own functions.

May I avail myself of this opportunity to state that $I$ believe the country is to be sincerely congratulated upon Hon. Carter Glass's appointment as our next Secretary of the Treasury. Nobody has done more in formulating and passing the Federal Reserve Act than he. Nobody has rendered greater services than he in keeping out of harm's way the schemers and dreamers that might have endangered or wrecked our banking structure. The country is deeply indebted to him today, and I am certain that as Secretary of the Treasury he will add further distinction to his record of public service. Through five years of intimate association, I have grown to know and sincerely admire this unassuming and unselfish man as one of our finest citizens and as a fearless fighter sacrificing himself without stint or reserve for whatever

- The report is significant, furthermore, in its unqualified recommendation that "the gold reserves of the country should be held by one central institution and that all banks should transfer any gold now held by them to the Bank of England." That is exactly the policy the Federal Reserve Board persistently urged upon Congress, a policy fortunately adopted and since enacted into law. Without such amendment it would have been impossible for the Federal Reserve System to accumulate the more than $\$ 2,000,000,000$ of gold which enabled it successfully to stand the unprecedented strain of financing the war. 
he deemed to be best for the country. I consider it a privilege to be permitted to pay him this tribute.

As military victory could not be won without the loss of lives, so financial victory could not be secured without economic sacrifices, not only of a material character, but also of principles which normally we hold dear. Inflation of prices and temporary surrender of individual freedom of operation are cases in point. Success having been achieved, we now are starting to wend our way back. We have fairly well reached the top of the mountain: we do not exactly know whether it is a peak or a high plateau. The transition period will keep us moving over it, and then gradually, as we ascended, we shall have to descend through the period of reconstruction, until we reach the normal level of the future.

Happily, in the case of finance, the course of our path lies fairly clearly ahead of us, because the relations between government and business had been defined by the Federal Reserve Act on a modern and satisfactory basis before the war broke out. In banking, the formula for private operation under government control had been found and put into effect. Conditions are not so clear with respect to other and similar problems, such, e.g., as the railroads, the financing of which forms a part of our program, which it would lead too far here to discuss. This only we might say in conclusion:

The war has accentuated and vastly accelerated the growth of government responsibility and influence in business. This development is world-wide at this time, it is natural, logical and inevitable. While it will tend to elevate business, there is danger that unless carefully safeguarded in both form and scope, it may tend to corrupt and to debauch government. It is this peril that we are facing at the moment of our proudest triumph, and it must be our serious concern that a national effort born in idealism should not bear the seeds of ultimate national decline. The reconstruction period places us face to face with this problem and it is during this period that thoughts will have to be developed leading to a solution entirely fair to the people.

In the case of the railroads, it is not solely a question between security holders and shippers; it is a question which affects on the one hand the integrity and safety of our future political life, on the 
other the very foundation of our economic development. The next year or two must bring forth legislation which ought to be for the railroads what the Federal Reserve Act has been for the banks. To find the proper formula will be a national contribution of the highest order. It will be a difficult task, but just for that reason one worthy of the efforts of the best minds of the country. It is not solely a question of railroad technique or finance. A larger problem is involved, one that will face us at every future step in the evolution of the relation between government and private enterprise, the problem of finding men big, trustworthy, expert and independent enough to measure up to the task, and to make the task independent, clean, non-partisan and dignified enough to measure up to the men.

Until that phase of the problem is solved, government regulation or operation in times of peace will remain imperfect and fraught with dangers threatening to outweigh its benefits. No time ever was more propitious than the present for making a determined start in this direction.

The reconstruction period is pregnant with the seeds of good or evil; what it brings forth will depend upon the care and devotion that the country gives to its problems. It is a period, as its name indicates, for constructive thought, not for destructive criticism. If the flower of our manhood is willing to serve the country during reconstruction and peace as it did in times of war, and if the country's new and larger duties, and its higher conceptions of them have taught it to want as its servants none but the truly best, then we may look into the future with hope and confidence that we may prove ourselves competent and faithful guardians of the sacred trust which this glorious period has placed into our hands. 